\title{
OBECNOŚĆ OJCÓW KOŚCIOŁA W PISMACH BŁ. KS. JOSEMARII ESCRIVÁ DE BALAGUER
}

W dniu 14 października 1993 r. odbył się w Rzymie Kongres Teologiczny na temat nauki bł. ks. Josemarii Escrivá de Balaguer. Zwracając się do uczestników Kongresu, Ojciec Święty Jan Paweł II, nie tylko zwrócił uwagę na doniosłość duchowego nauczania bł. Josemarii w kontekście nowej ewangelizacji, ale podkreślił, że nauczanie to powinno stać się także zaczynem dla myśli teologicznej: „Zapraszam was do kontynuowania tego zadania, ponieważ Josemaría Escrivá de Balaguer, podobnie jak inne wielkie postaci współczesnej historii Kościoła, może być źródłem natchnienia również dla myśli teologicznej"1. Zbliżająca się setna rocznica urodzin ks. Josemarii Escrivá jest szczególną okazją, aby przypomnieć główne zagadnienia teologiczne z jego nauczania. Jednym $\mathrm{z}$ nich jest stosunek omawianego autora do dziedzictwa myśli patrystycznej.

B1. ks. Josemaría Escrivá de Balaguer urodził się 9 stycznia 1902 r. w Barbastro, w prowincji Huesca w Hiszpanii. Ukończył studia seminaryjne w Logroño i Saragossie, a także studia prawa cywilnego na uniwersytecie w Saragossie, uzyskując doktorat w zakresie prawa na uniwersytecie madryckim oraz doktorat w zakresie teologii na Papieskim Uniwersytecie Lateraneńskim w Rzymie. W 1925 r. przyjął święcenia kapłańskie. Jako kapłan pracował w diecezji Saragossa, a potem w Madrycie. W 1928 r. założył Opus Dei, które w 1950 r. uzyskało aprobatę Stolicy Apostolskiej. Od założenia Opus Dei ks. Josemaría Escrivá poświęcił się całkowicie pracy apostolskiej na rzecz Dzieła. Zmarł w opinii świętości 26 czerwca 1975 r. w Rzymie, a w 1992 r. został beatyfikowany przez pap. Jana Pawła II.

1. Charakterystyka pism. Intensywna praca związana z założeniem i kierowaniem Opus Dei oraz bardzo rozległa praca duszpasterska nie pozwalały ks. Escrivá na szeroką działalność pisarską, chociaż doceniał on wartość słowa pisanego w głoszeniu Ewangelii: „Choć czuję się pozbawiony cnoty i wiedzy

\footnotetext{
${ }^{1}$ „Biuletyn Informacyjny Opus Dei”, 1996, nr 11, s. 5.
} 
(pokora jest prawdą bez obłudy) - wyznawał - pragnąłbym napisać kilka książek pełnych ognia, które obiegłyby świat jak żywy płomień, rozpalając swym światłem i żarem ludzi, przekształcając biedne serca w żagwie, by ofiarować je Jezusowi jako rubiny do Jego królewskiej korony"2. Pragnienie ks. Josemarii spełniło się: w 1934 r. ukazały się jego Rozważania duchowe (Considerationes espirituales, Cuenca), zawierające krótkie myśli i refleksje, ujęte niekiedy w formę sentencji, dotyczące życia duchowego. Ich poszerzona wersja została opublikowana w 1939 r. pod tytułem Droga (Camino, Madrid) ${ }^{3}$. W 1934 r. ukazał się także Różaniec święty (Santo Rosario, Madrid) - ksiązeczka zawierająca rozważania pietnastu tajemnic życia Chrystusa. W $1944 \mathrm{r}$. ks. Escrivá opublikował swoją pracę doktorską La Abadesa de la Huelgas (Madrid). Później, także niektóre z jego często głoszonych homilii zostały wydane w zbiorach: Kochać Kościót (Amar a la Iglesia, Madrid 1968) oraz To Chrystus przechodzi (Es Cristo Que pasa, Madrid 1973). Po śmierci autora przygotowano wydanie kolejnego tomu jego homilii: Przyjaciele Boga (Amigos de Dios, Madrid 1977). Pośmiertnie ukazały się także: Droga krzyżowa (Via Crucis, Madrid 1981), Bruzda (Surco, Madrid 1986) i Kużnia (Forja, Madrid 1988). Dwie ostatnie pozycje, podobnie jak Droga, zawierają krótkie teksty do rozważań ${ }^{4}$.

Pisma bł. ks. Josemarii można ogólnie podzielić na dwie grupy: homilie (Kochać Kościót, Przyjaciele Boga, To Chrystus przechodzi) oraz rozważania (Droga, Bruzda, Kuźnia, Droga Krzyżowa, Różaniec święty). Nie stanowią one systematycznych traktatów teologicznych, chociaż ich bogata i głęboka duchowość zawiera treści teologiczne z całym bogactwem Tradycji Kościoła, zwłaszcza w zakresie myśli patrystycznej. Nauka Ojców Kościoła jest bowiem obecna zarówno w wymienionych zbiorach homilii jak i w tekstach takich rozważań, jak: Droga, Bruzda i Kuźnia. Stąd też wymienione pisma ks. Josemarii Escrivá staną się podstawą dla niniejszych rozważań.

2. Tradycja patrystyczna w pismach ks. Josemarii Escrivá. Już pobieżne zapoznanie się z pismami bł. ks. Josemarii pozwala zauważyć żywą obecność myśli patrystycznej w interpretacji Słowa Bożego i zjawisk życia religijnego. Powyższe stwierdzenie uzasadniają poszczególne odwołania autora do tekstów pisarzy starożytnych. Zostanie to ukazane na podstawie jego homilii i rozważań.

${ }^{2}$ Cyt. za A. del Portillo, Wprowadzenie, w: J. Escrivá, Droga. Bruzda. Kuźnia /br. tłum./, Katowice 2000, s. 571.

${ }^{3}$ Książka ta została przetłumaczona dotychczas na 41 języków. W języku polskim została wydana czterokrotnie przez Księgarnię św. Jacka, Katowice $(1982,1984,1992,2000)$ i trzykrotnie w Londynie (Scriptor 1966, 1969, 1981).

${ }^{4}$ Wymienione prace nie stanowią kompletnego wydania pism bł. ks. Josemarii. Istnieje jeszcze wiele pism dotąd nie publikowanych (por. A. del Portillo, Wprowadzenie, w. J. Escrivá de Balaguer, To Chrystus przechodzi, thum. A. Kajzerek, Katowice 1992, s. 10). 
W homiliach ograniczymy się tylko do wyliczenia cytowanych tekstów z dzieł Ojców Kościoła. Natomiast w przypadku rozważań, aby ukazać specyficzną formę powoływania się na chrześcijańskich autorów starożytnych, poszczególne fragmenty z pism ks. Josemarii Escrivá zostaną zacytowane.

a) homili e. To Chrystus przechod $z i^{5}$ - jest to zbiór 18 homilii związanych z Rokiem Liturgicznym (od Adwentu do niedzieli Chrystusa Króla), wygłoszonych w latach 1951-1971. Ich centralnym tematem jest wezwanie do świętego przeżywania czasu codziennego, w chrześcijańskiej uczciwości i aktywności wypełniającej wszystkie godziny dnia. W homiliach tych ks. Escrivá cytuje następujących autorów wczesnochrześcijańskich: Ambroży (2), Augustyn (13), Bazyli Wielki (1), Cyprian (1), Cyryl Aleksandryjski (2), Cyryl Jerozolimski (1), Grzegorz Wielki (5), Hieronim (1), Ignacy Antiocheński (1), Jan Chryzostom (17), Jan Damasceński (1), Justyn (1), Klemens Aleksandryjski (2), Tertulian (2) oraz tekst apokryficznej Ewangelii Dziecięctwa św. Tomasza (1).

Przyjaciele Boga 6 - to zbiór 18 homilii, wygłoszonych w latach 1941-1968 r., w których ks. Josemaría Escrivá za główny temat obrał sobie cnoty chrześcijańskie. Nawiązuje w nich do następujących autorów patrystycznych: Ambroży (4), Augustyn (16), Bazyli Wielki (2), Cyryl Aleksandryjski (1), Grzegorz z Nazjanzu (1), Grzegorz Wielki (7), Grzegorz z Nyssy (2), Hieronim (3), Ignacy Antiocheński (1), Jan Chryzostom (7), Jan Damasceński (1), Kasjan (1), Klemens Aleksandryjski (1), Leon Wielki (1), Maksym Wyznawca (1), Marek Pustelnik (1), Orygenes (4), Pseudo-Makary (1), Tertulian (1) oraz do fragmentu Listu do Diogneta (1), Soboru Efeskiego (1) i Symbolu Quicumque (1).

Kochać Kościót zawiera 4 tylko homilie na temat Kościoła, wygłoszone w latach 1967-1973. Ks. Escrivá cytuje w nich następujących Ojców Kościoła: Ambroży (1), Augustyn (6), Cyprian (2), Cyryl (1), Grzegorz Wielki (1), Jan Chryzostom (1), Jan Damasceński (1).

b) rozważ ania. Droga. Bruzda. Kuźnia to łączne wydanie trzech zbiorów krótkich myśli i spostrzeżeń na temat życia religijnego, ułożonych tematycznie (np. „Modlitwa”, ,Umiłowanie prawdy”, ,Praca”) i ponumerowanych (Droga - 999, Bruzda - 1000, Kuźnia - 1055). W tych krótkich tekstach spotykamy także nawiązania do Ojców Kościoła: „, Oderwij się od stworzeń aż do ogołocenia się z nich. Bowiem szatan - jak powiada papież św. Grzegorz - nie posiada na świecie nic własnego i nagi staje do potyczki”; „Bądź odważny. Powiedz, że jesteś dla Niego bardziej szalony niż Maria Magdalena, niż Teresa i mała Tereska [...] bardziej narwany niż Augustyn i Dominik, i Franciszek, niż

\footnotetext{
${ }^{5}$ Por. To Chrystus przechodzi, tłum. A. Kajzerek, Katowice 1992, ss. 273.

${ }^{6}$ Por. Przyjaciele Boga, thum. J. Jarco, Katowice 1996, ss. 371.

Por. Kochać Kościót, tłum. A. Baranek, Katowice 1994, ss. 132.

${ }^{8}$ Por. Droga. Bruzda. Kuźnia, brak nazwiska thumacza, Katowice-Ząbki 2000.

${ }^{9}$ Droga 149, s. 56.
} 
Ignacy i Franciszek Ksawery”10, „Już święty biskup z Hippony przestrzegał: «Kto nie idzie naprzód, ten się cofa”»" ", „Zacznij od przyjęcia tej prawdy w swoim sercu. Będzie ono wiecznie niespokojne - jak napisał św. Augustyn - dopóki całkowicie nie spocznie w Bogu”12, „Ojciec powiedział mi, że mogę zostać «drugim» świętym Augustynem, mimo mojej przeszłości. Ale musisz zerwać z przeszłością mężnie i radykalnie, jak święty biskup z Hippony" "3 „Możemy powiedzieć, za św. Augustynem, że złe namiętności ściągają nas w dół”" ${ }^{14}$, „Jakże wspaniale odnoszą się do dzieci Bożych te słowa świętego Ambrożego! Mówi o osiołku przywiązanym do oślicy, którego Jezus potrzebował na swój triumfalny wjazd do Jerozolimy, i dodaje: «Tylko rozkaz Pana mógł go odwiązać. Uwolniły go ręce Apostołów. Do podobnego czynu potrzebne są odpowiedni tryb życia i szczególna łaska. Bądź ty także apostołem, abyś mógł wyzwolić uwięzionych»"15.

Z zestawienia cytowanych przez ks. Josemarię Escrivá starożytnych autorów chrześcijańskich wynika, że odwoływał się on zarówno do autorytetu Zachodnich jak i Wschodnich Ojców Kościoła, jak też i do myśli innych pisarzy wczesnochrześcijańskich, formalnie nie zaliczanych do Ojców Kościoła, takich jak: Orygenes, Tertulian, Klemens Aleksandryjski. Sporadycznie występują także odwołania do anonimowych tekstów patrystycznych (np. List do Diogneta), tekstów soborowych (np. Sobór Efeski, Symbol Quicumque) i apokryfów (np. Ewangelia Dziecięctwa św. Tomasza). Pod względem częstotliwości powoływania się na poszczególnych autorów, najważniejszy jest św. Augustyn, którego ks. Escrivá cytuje 40 razy, w dalszej zaś kolejności: św. Jan Chryzostom (25), św. Grzegorz Wielki (14), św. Ambroży (8). Wśród dzieł zaś św. Augustyna najczęściej sięgał do Enarrationes in Psalmos oraz traktatu In Ioannis Evangelium. $\mathrm{Z}$ innych tekstów dość często cytowanych należy wymienić: homilie In Mathaeum św. Jana Chryzostoma, Homiliae in Evangelia papieża św. Grzegorza Wielkiego i Expositio Evangelii secundum Lucam św. Ambrożego. Najwięcej odwołań do nauki patrystycznej występuje w homiliach. Na przykład w homilii „Wolność darem Bożym”, wygłoszonej 10 czerwca 1956 r., a opublikowanej w zbiorze Przyjaciele Boga ${ }^{16}$, ks. Escrivá de Balaguer cytuje aż 8 fragmentów z dzieł patrystycznych: „Dlatego właśnie rozumiem doskonale słowa biskupa z Hippony, które brzmią jak cudowny hymn wolności: «Bóg, który stworzył cię bez ciebie, nie zbawi cię bez ciebie»”17, „Wolność jednak

\footnotetext{
10 Tamże 402, s. 118.

11 Bruzda 165, s. 334.

12 Tamże 796, s. 512.

13 Tamże 838, s. 522.

14 Kuźnia 411, s. 690.

15 Tamże 672, s. 762.

16 Tamże, s. 53-71.

17 Tamże, s. 54, cytat z: Sermo 169, 13; PL 38, 923.
} 
sama z siebie nie wystarczy, potrzebuje busoli wskazującej kierunek. «Dusza nie może iść naprzód bez kogoś, kto nią kieruje; dlatego właśnie została odkupiona, aby mogła mieć za Króla Chrystusa, którego jarzmo jest słodkie a brzemię lekkie (Mt 11, 30), a nie diabła, którego władza jest przytłaczająca»" 18 , „Coraz bardziej wzrasta moje pragnienie głoszenia tego niezgłębionego bogactwa chrześcijan, wolności i chwały dzieci Bożych! Przejawia się ono dobra wolq, która uczy nas «podążania za dobrem po odróżnieniu go od zła»"19, „Ale przez całe nasze życie - i to każdego dnia - winniśmy odnawiać postanowienie miłowania Boga ponad wszystko. "Chrześcijaninem, prawdziwym chrześcijaninem, jest ten, kto poddaje się władzy jedynego Słowa Bożego»"20, „Nasza Święta Matka Kościół zawsze opowiadał się za wolnością i odrzucał wszelkie fatalizmy, dawne i nowe. Podkreśla, że każdy człowiek jest panem swego przeznaczenia, na dobre i na złe: «Ci, którzy czynili dobrze, pójdą do życia wiecznego, którzy natomiast czynili zło, pójdą w ogień wieczny»"21, „Wciąż od nowa zdumiewa nas ta niesłychana możliwość decydowania, twoja i moja, nas wszystkich, która jest jednocześnie znakiem naszej godności. «Grzech jest złem dobrowolnym do tego stopnia, że w żaden sposób nie byłby grzechem, gdyby nie miał swego początku w woli; to twierdzenie jest tak oczywiste, że zgadzają się z nim owi nieliczni mędrcy i owi liczni ignoranci, którzy zamieszkują świat” ${ }^{22}$, „Ponownie wznoszę swe serce ku Bogu w akcie dziękczynienia, ponieważ nic nie przeszkadzało $\mathrm{Mu}$, by stworzył nas niezdolnymi do grzechu, z nieprzepartym dążeniem do dobra, «uznał jednak, że Jego słudzy będą lepsi, jeżeli będą Mu służyć dobrowolnie»”23 , „Nasza wiara chrześcijańska nakazuje nam, żebyśmy wszystkim i wszędzie zapewniali klimat wolności, poczynając od wszelkiego rodzaju przymusu w okazywaniu wiary. «Jeśli jesteśmy doprowadzani do Chrystusa siłą, wierzymy nie chcąć wierzyć; jest to owoc przemocy, a nie wolności. Człowiek przymuszony może wejść do kościoła, podejść do ołtarza, może nawet przyjąć sakrament - ale wierzyć może jedynie ten, kto chce wierzyć»" 24 , „Tamto «compelle intrare» nie oznacza przemocy fizycznej ani moralnej, odzwierciedla porywającą siłę przykładu chrześcijańskiego, który jest tak skuteczny jak moc Boża: «Przyjrzyjcie się, jak pociąga nas Ojciec: zachwyca swoim nauczaniem, nie narzuca żadnej konieczności. W ten sposób przyciąga do Siebie" ${ }^{25}$.

18 Tamże, s. 57, cytat z: Orygenes, Commentarii in Epistolam ad Romanos, 5, 6; PG 14, 1034 1035.

19 Tamże, s. 58, cytat z: Maximus Cofessor, Capita de charitate, 2, 32, PG 90, 995.

20 Tamże, s. 59, cytat z: Orygenes, Contra Celsum, VIII 36, PG 11, 1571.

21 Tamże, s. 64-65, cytat z: symbolu wiary Quicumque.

22 Tamże, s. 65, cytat z: Augustinus, De vera religione, 14, 27, PL 34, 133.

23 Tamże, s. 65, cytat z tegoż, PL 34, 134.

${ }^{24}$ Tamże s. 68, cytat z: Augustinus, In Ioannis Evangelium trac., 26, 2, PL 35, 1607.

25 Tamże, s. 69, cytat z tegoż, 26, 7, PL 35, 1610. 
W homiliach, jak zostało to wyżej ukazane, ks. Josemaría Escrivá przytacza zazwyczaj dłuższe fragmenty z dzieł Ojców Kościoła, podając dokładnie ich autora i tytuł dzieła ${ }^{26}$. Tylko niekiedy mówi o autorze w sposób ogólny ${ }^{27}$ lub określa go zamiennie (np. Augustyn jako „święty biskup z Hippony”). Z kolei w rozważaniach powołuje się na naukę Ojców Kościoła potocznie, przywołując znane powiedzenia (np. Bruzda 165, 796), bardziej nawiązując do ich życia niż myśli.

3. Rola Tradycji patrystycznej w pismach bł. ks. Josemarii. Homilie ks. Josemarii opublikowane w trzech zbiorach - To Chrystus przechodzi, Przyjaciele Boga i Kochać Kościót nie były przygotowane przez autora jako studia lub rozprawy na określone tematy. Wcześniej zostały one wygłoszone na żywo do ludzi o różnej mentalności, pochodzących z różnych grup społecznych. Jednak ich treść autor oparł na mocnym fundamencie Słowa Bożego i Tradycji Kościoła. Cytując dłuższe fragmenty z pism patrystycznych podkreśla w ten sposób, że nauka ta jest nie tylko nadal aktualna, ale pomimo upływu wieków wciąż żywa, nie wymagająca dodatkowych wyjaśnień współczesnemu chrześcijaninowi. „Dlatego też - pisze A. del Portillo - nie może nas dziwić zbieżność komentarzy prałata Escrivá de Balaguera z nauką Ojców Kościoła, którzy żyli ponad piętnaście wieków temu. $Z$ tej też przyczyny ich cytaty, ukazują się nam w sposób naturalnie złączony z tekstami homilii i wiernie współbrzmią z Tradycją Kościoła" ${ }^{28}$. Należy podkreślić, że w homiliach ks. Escrivá cytowane teksty patrystyczne nie spełniają funkcji argumentacyjnej, potwierdzającej zasadność postawionej tezy, ale został w nich wyeksponowany autorytet $\mathrm{Oj}$ ców Kościoła jako nauczycieli wiary. Z kolei w rozważaniach bardziej akcentuje on rolę Ojców Kościoła jako wzorów do naśladowania (por. Bruzda, 838), stąd wskazuje na niektóre cechy ich charakteru (por. Droga 402) i umiejętnie wyprowadza naukę z ich doświadczenia życiowego (por. Kuźnia 411). Podsumowując należy stwierdzić, że w pismach bł. ks. Josemarii Escrivá de Balaguer nauka patrystyczna stanowi fundament w interpretacji Słowa Bożego i jego odniesienia do życia. Omawiany autor w sposób żywy ukazuje współczesnemu chrześcijaninowi Ojców Kościoła jako nauczycieli wiary i wzory do naśladowania.

${ }^{26}$ Bardzo rzadko powołuje się na naukę konkretnego pisarza w sposób ogólny, np.: „Święty Justyn, mówiąc o pracy Jezusa zapewnia, że wyrabiał pługi i jarzma" (To Chrystus przechodzi, s. 74).

${ }^{27}$ Np. ,Jak określić - pyta jeden z katolickich pisarzy pierwszych wieków - szczęście małżeństwa zjednoczonego przez Kościół, który potwierdza wzajemne oddanie się, pieczętuje je świetością, ogłasza je przez aniołów i sam Bóg Ojciec ma je za święte?” (Tamże, s. 56).

${ }^{28}$ Wprowadzenie, w: J. Escrivá de Balaguer, To Chrystus przechodzi, s. 11. 


\title{
LA PRESENCIA DE LOS PADRES DE LA IGLESIA EN LAS OBRAS DE JOSEMARÍA ESCRIVÁ DE BALAGUER
}

\author{
(Resumen)
}

Mons. Josemaría Escrivá de Balaguer (1902-1975), el fundator de Opus Dei es el autor de las homilias (Amar a la Iglesia, Madrid 1968; Es Cristo Que pasa, Madrid 1973; Amigos de Dios, Madrid 1977) y de las meditaciónes (Camino, Madrid 1939; Surco, Madrid 1986; Forja, Madrid 1988). En sus obras a menudo refiere a la doctrina de los Padres de la Iglesia, especialmente San Augustin, San Juan Crisostomo, San Gregorio Magno y San Ambrogio. De esa manera subraya que la ciencia de los Padres es actual y real para el cristiano contemporaneo. En sus homilias, muestra ante todo los Padres de la Iglesia como maestros de fe, en cambio en las meditaciónes presenta los como ejemplos de la vida moral. 